\title{
A Discussion on Integration of Academic Competence and Ideological Morality of Postgraduates
}

\author{
Yanhui $\mathrm{CHEN}^{1, \text { a }}$ \\ ${ }^{1}$ Graduate School of Jilin Agricultural University, 130118, Changchun, China \\ aemail:yanhuichenc@126.com
}

Keywords: Postgraduate; Academic competence; Ideology and morality; Integration

\begin{abstract}
As China and graduate academic strength and force the military to prepare, have their academic and moral level of direct importance to improve the impact of academic ability, but also is an important part of their sound moral character. It is an issue worthy of attention in cultivation of postgraduates at the present times to realize integration of academic competence and ideological morality.
\end{abstract}

\section{Introduction}

At present, postgraduate education is in rapid development with gradual increase in the enrollment scale year by year, China has now become one of the countries with the largest number of postgraduates in the world. When we feel gratified by the large number of high-level talents, we are also deeply concerned and worried about a series of emerging academic and moral problems in postgraduates. In essence, academic and moral problems are directly related to personal moral traits and integrity. Although there are many factors leading to anomie of academic morality of postgraduates, educators need to make in-depth reflections : what are the objectives for cultivation of academic competence and ideological morality of postgraduates? and how to realize integration of academic competence and ideological morality. Those problems are worth pondering.

\section{Objectives for cultivation of academic competence of postgraduates}

As the top-level design of talent cultivation, postgraduate education is of vital significance to our nation and society. It is stipulated in Article IV of the Degree Management Statute of People's Republic of China that qualified postgraduates shall "acquire a solid mastery of basic theory and systemic special knowledge" and "be capable of scientific research or independently take on specialized technical work". And it also stipulates that qualified doctoral candidates shall "acquire a solid mastery of basic theory and systemic, in-depth special knowledge", "be capable of scientific research independently" and "make creative achievements in science or special technology”. Hence, cultivation of postgraduates shall be focused on ability of theoretical grasp, scientific research capability and practical ability, and the three kinds of abilities are covered in academic competence $^{[1]}$. The academic competence of postgraduates refers to the ability obtained by cultivation during study for a master's degree or doctorate, which includes three elements, namely ability of theoretical grasp, scientific research capability and practical ability and overall quality integrating honesty, cooperation and humanist spirit. It is found by summary that in the cultivation plans of various universities, the foresaid three elements are frequently mentioned in requirements of academic competence of postgraduates along with other qualities such as innovation, team spirit and academic morality. This is closely related to the historical background of the present times. In today's world seeing rapid scientific and technological development, all the nations around the world are paying high attention to cultivation of innovative talents and team spirit. Accordingly, we can sum up the goals for academic competence of postgraduate overall quality ${ }^{[2]}$. Wherein, scientific research ability contains consciousness of problems, academic sensitivity, ability of critical thinking, ability to analyze problems, capacity of generalization and innovation. Practice 
capability includes hands-on skills, language competence and ability of professional development. And overall quality refers to humanist spirit, team spirit and academic morality.

\section{Value Goals of Ideological and Moral Construction for Postgraduate}

Academic and moral education for postgraduates aims to guide those students, and provide scientific knowledge while shaping their inner moral traits. Moral education is the education of human being and plays a role of spiritual support in helping human being to achieve a happier life. Academic activities of postgraduates reflect their inner charm and integrated personality in realistic activities and academic morality provide internal guarantee for people in academic activities, If the spiritual drive is missing, researchers would shrink back at the sight of arduous, long-term and complicated academic activities. Under that circumstance, there would be few academic achievements let alone construction of perfect moral personality.

In terms of actual situation of academic and moral education for postgraduates, it is a education project striving for sustainable development. While, from the perspective of significance value, academic and moral education for postgraduates is not only the spiritual source for academic competence and level of postgraduates but also lays a foundation for other social service and national construction ${ }^{[3]}$. It is the the sustainable healthy development that academic and moral education for postgraduates pursues. Academic and moral education for postgraduates is like operation of an ecosystem and requires full consideration of all relevant factors, namely education activities inside the campus and social enlightenment outside the campus, which shall be included into the academic and moral education system for postgraduates. In addition, only when the system is stable and well-coordinated, can the academic and moral education for postgraduates be carried out smoothly and achieve sound development.

\section{Integration of Academic and Ideological Morality of Postgraduates}

Understanding of academic morality stipulations, consciously compliance with and maintenance of academic morality are the objectives for construction of academic morality for postgraduates based on the identity with ideological morality of postgraduates from deep inside, which is derived from quality of academic competence. Therefore, it is of great importance to study integration of cultivation of academic competence and construction of ideological morality for postgraduates.

Cultivation of academic competence has certain effects on realization of ideological and moral value goals.

When it comes to realization of ideological and moral values objectives for postgraduates, direct and common practice is to give instruction, restriction, demonstration and punishment on institution, ideology and operational norms for the purpose of compliance with academic morality so as to arouse vigilance or fear in violating academic and moral boundaries from psychology and action of postgraduates, thus, the students can studiously avoid the behaviors violating academic morality ${ }^{[4]}$. Such kind of instruction is of certain positive meaning for appeal of academic morality value for postgraduates. Superficially speaking, cultivation of such academic competence has no direct relation to study of academic morality of postgraduates because the former is a learning or vocational skill, while the latter belongs to a kind of values. However, enhancement of academic competence means increase in positivity towards ego and academic cultivation of postgraduates, and such increase will indirectly influence their academic morality values and lead them to identify and comply with academic morality consciously. On this account, cultivation of academic competence has indirect effect on realization of ideological and moral values objectives ${ }^{[5]}$. 
Cultivation of academic competence has fundamental effect on realization of ideological and moral values objectives for postgraduates.

Understanding, cultivation of and compliance with academic morality of postgraduates is a process proceeding from the interior to the exterior. Individuals with research capabilities, on one hand, are more likely to take a positive attitude towards academic morality on the basis of self-identity; on the other hand, with the support and prop of academic competence, they don't need to gain academic "advantages" by risk-taking behavior of overstepping academic morality boundaries $^{[6]}$. On the contrary, a postgraduate student with relatively lower academic competence is more liable to offend dignity of academic morality to finish or realize his academic "benefits". Therefore, cultivation of academic competence has fundamental effect on realization of pursuit of academic and moral value for postgraduates ${ }^{[7]}$. In general, postgraduates are aging from 22 to 30 , and more mature with certain cognitive competence and judging ability of academic morality. As a result, only by improving academic competence and research capability can academic anomie behavior be completely eradicated. Meanwhile, it is a vital part in construction of study style in institutions of higher learning ${ }^{[8]}$. Whereas, improvement of academic competence and research capability of postgraduates can be achieved in a long process that requires joint efforts from the institutions of higher learning, tutors and the postgraduates. The institutions of higher learning create good research environment for postgraduates and increase investment in scientific research. As we all known, the quality of education in the foothold for the institutions of higher learning, which has certain influence on overall quality and academic atmosphere there. Hence, the institutions of higher learning shall also strengthen team construction of postgraduate tutors, deepen teaching reform and give full play to the role of tutors in teaching by personal example as well as verbal instruction. Meanwhile, tutors shall guide students to consciously abide by the academic norms and improve academic competence. Finally, academic lectures, forums, salons and reading clubs and other activities shall be organized in institutions of higher learning regularly to create good learning environment, thick academic atmosphere for postgraduates so as to help students in academic exchange and experience, broadening their academic views and further improve research capability $^{[9]}$.

\section{Conclusions}

With regards to moral construction of postgraduates, although external forces are important to guidance and supervision of academic moral behaviors of students, it is still necessary and fundamental for improvement in academic competence to realize value of academic morality of the students. For this purpose, all the students shall be given independent ideology and action capability to acquire independence in ideology and action and enable them to realize and shoulder basic value of academic morality with a sharing attitude towards learning. It requires us to realize integration of cultivation of academic competence and moral construction for postgraduates in practice: (1) we can excessively depend on force and effects of external punishment measures; (2) we shall enhance academic competence and research capability ; (3) we shall further improve the evaluation and supervision mechanism of academic achievements.

\section{References}

[1] Hui Rangsong. Academic Morality of Postgraduates -- Autonomy And Heteronomy [J]. Journal of Medical Postgraduates, 2010, (3):331-333.

[2] Ma Gelan. Root Causes and Countermeasures for Academic Morality Anomie of Some Postgraduates [J]. Journal of Higher Education, 2010, (1):80-82.

[3] Peng Shuzhi. Return to Conscious Academic Cultivation -- A Brief Discussion on Cultivation of Academic Consciousness of Postgraduates [J]. Academic Degrees \& Graduate 
Education,2008,(1):1- 2.

[4] Chen Chaocuan. A Discussion on Strengthening Academic Moral Education of Postgraduates [J]. Academic Degrees \& Graduate Education,2001,(12):30- 33.

[5] Li Zuchao. An Analysis of Education on Morality of Scientific Research for Postgraduates under Guidance of Tutors [J]. Modern Education Management,2009,(3): 123- 125.

[6] Guo Dexia. Anomie and System Construction of Academic Morality for Postgraduates [J]. Higher Education Development and Evaluation,2010,(1):78- 86.

[7] Yang Zhijun. Moral Education for Postgraduate Emphatically Depending on Moral Internalization[J]. Journal of Chongqing University of Science and Technology,2012(12).

[8] Zhu Zhiyong. Academic Competence of Postgraduates : A Theoretical Framework based on Policy Text Analysis [J]. Tsinghua Journal of Education,2012,(6):92 -99.

[9] Zhou Yezhong. Target Conversion and Model Reconstruction: The Only Road for Reform of Postgraduate Education in China [J]. Academic Degrees \& Graduate Education,2010,(4):57一 60. 